\title{
PENGARUH SOLVABILITAS DAN INTELLECTUAL CAPITAL TERHADAP EFFECTIVE TAX RATE MELALUI KUALITAS INFORMASI AKUNTANS I
}

\author{
Sihar Tambun \\ E-mail: sihar.tambun@uta45jakarta.ac.id \\ Program Studi Akuntansi, Universitas 17 Agustus 1945 Jakarta
}

\begin{abstract}
Abstrak: Artikel ini memaparkan pengaruh dari solvabilitas dan intellectual capital pada kualitas informasi akuntansi, serta dampaknya terhadap effective tax rate. Solvabilitas dan inntellectual capital sebagai variabel independen dalam penelitian ini. Kualitas informasi akuntansi sebagai varibael mediasi, dan efektive tax rate sebagai variable dependen. Sample dipilih dengan metode purposive sampling, dan menghasilkan 20 emiten dari sektor industri barang konsumsi periode tahun 2013-2017. Metode analisis menggunakan metode estimasi ordinary least square untuk model yang menguji pengaruh langsung. Untuk pengujian pengaruh tidak langsung, menggunakan metode two least square. Hasil penelitian membuktikan bahwa intellectual capital dan solvabilitas mempengaruhi kualitas informasi akuntansi. Kemudian, kualitas informasi akuntansi dan intellectual capital mempengaruhi efketif tax rate. Secara tidak langsung, intellectual capital dan solvabilitas mempengaruhi efektive tax rate melalui kualitas informasi akuntansi.
\end{abstract}

Kata Kunci: Solvabilitas, Intellectual Capital, Kualitas Informasi Akuntansi, Tax Avoidance, Efektive Tax Rate

Abstract: This article describes the effect of solvency and intellectual capital on the quality of accounting
information, and its impact on effective tax rate. Solvency and intellectual capital as independent variables in
this research. The quality of accounting information as variable mediation, and the effectiveness tax rate as the
dependent variable. Sample is chosen by purposive sampling method, and produces 20 emitters from consumer
goods industry sector in the period of $2013-2017$. The analytical method uses ordinary least square estimation
methods for models that test direct effect. For testing indirect effect, using two least square methods. The results
prove that intellectual capital and solvency affect the quality of accounting information. Then, the quality of
accounting information and intellectual capital affects the effective tax rate. Indirectly, intellectual capital and
solvency affect the effectiveness of tax rate through the quality of accounting information.

Keywords: Solvency, Intellectual Capital, Quality Accounting Information, Tax Avoidance, Effective Tax Rate

\section{PENDAHULUAN}

\subsection{Latar Belakang}

Tujuan setiap perusahaan adalah meningkatkan nilai. Nilai dari setiap perusahaan digambarkan dari besarnya divenden ataupun return yang diperoleh dari aktivitas investasi. Sumberdaya perusahaan senantiasa dimaksimalkan manfaatnya demi tercapainya tujuan perusahaan. Upaya berkelanjutan dilakukan untuk meningkatkan pendapatan dan disisi lain diupayakan efisiensi di semua bidang. Sumberdaya yang menjadi bagian penting dari perusahaan sangatlah beragam, diantaranya sumber daya manusia dan sumber daya modal. Sumberdaya manusia adalah sumberdaya yang paling strategis, karena semberdaya manusia mengelola sumberdaya lainnya yang ada diperusahaan. Sumberdaya modal juga sangat penting, terutama bila modal berasal dari pinjaman (hutang). Manajemen harus memastikan bahwa modal pinjaman tersebut produktif dan bisa menutupi pembayaran bunga dan pengembalian hutang tersebut. Peran sumberdaya manusia sangat penting dalam hal ini, untuk mengelolah modal yang berasal dari hutang, serta mengelola dan memaksimalkan sumber daya yang ada. Hasil pengelolaan dan kinerja dinyatakan di dalam laporan keuangan. Informasi yang dilaporkan dalam laporan keuangan disebut dengan informasi akuntansi. Informasi akuntansi yang baik harus disertai dengan catatan atas laporan keuangan, yang berisi penjelasakan dan pencapaian perusahaan selama periode tersebut. Termasuk informasi penggunakan sumberdaya dan juga strategi efisiensi yang dilakukan.

Salah satu strategi efisiensi yang sering dilakukan oleh perusahaan adalah efisiensi pajak. Strategi efisiensi pajak umumnya menggunakan tax avoidance. Tax avoidance adalah cara yang digunakan untuk menghindari pembayaran pajak secara legal yang dilakukan oleh wajib pajak dengan cara yang dilakukan adalah mengurangi jumlah pajak terutangnya tanpa melanggar peraturan perpajakan atau dengan istilah lainnya dengan mencari kelemahan peraturan (Hutagaol, 2007). Dengan kata lain, tax avoidance adalah salah satu metode perencanaan pajak untuk tujuan efisiensi, dengan cara memanfaatkan kemudahan dan fasiltas yang dinyatakan dalam peraturan perpajakan. Bahkan memanfaatkan kelemahan dari peraturan perpajakan demi tujuan efisiensi. Banyak perusahaan di Indonesia yang berusaha melakukan efisiensi dari sektor perpajakan ini. Metode efisiensi pajak dengan tax avoidance masih lebih baik bila dibandingkan dengan metode tax evasion. Metode tax evasion ini cenderung melakukan tindak kejahatan secara terbuka, dengan sengaja melanggar peraturan pajak, dengan sengaja tidak membayar pajak, atau dengan sengaja menggelapkan pajak. Tindakan Tax evasion tentu tidak direkomendasikan karena merupakan tindak kejahatan di bidang perpajakan. Selain itu, tindakan tax evasion juga dapat mengurangi pendapatan Negara dari sector pajak. Pendapatan pemerintah dari sektor pajak hingga 
saat ini masih menjadi sumber utama penerimaan Negara untuk mendanai APBN. Data pada table 1 menginformasikan bahwa kepatuhan wajib pajak pada tahun 2011 hingga tahun 2016 terus meningkat. Meskipun terus meningkat, sebenarnya wajib pajak yang belum patuh masih sangat banyak. Diharapkan program efisiensi pajak, melalui tindakan tax evoidance yang dilakukan oleh perusahaan, hendaknya tidak mengurangi rasio kepatuhan wajib pajak di Indonesia.

Table 1: Rasio Kepatuhan Penyampaian SPT Tahunan PPh Tahun 2011- 2016

\begin{tabular}{|l|r|r|r|r|r|r|}
\hline \multicolumn{1}{|c|}{ Keterangan } & \multicolumn{1}{c|}{2016} & \multicolumn{1}{c|}{2015} & \multicolumn{1}{c|}{2014} & \multicolumn{1}{c|}{2013} & \multicolumn{1}{c|}{2012} & 2011 \\
\hline WP Tedaftar & \multicolumn{1}{c|}{$32,769,215$} & $30,044,103$ & $27,397,256$ & $24,347,763$ & $22,030,583$ & $18,640,757$ \\
\hline WP Terdaftar Wajib SPT & $20,165,718$ & $18,159,840$ & $18,375,833$ & $17,731,736$ & $17,659,278$ & $17,694,317$ \\
\hline SPT Tahanun PPh & $11,525,628$ & $10,927,529$ & $10,852,304$ & $9,966,834$ & $9,237,948$ & $8,180,963$ \\
\hline Rasio Kepatuhan & $63,15 \%$ & $60,42 \%$ & $59,12 \%$ & $56,21 \%$ & $52,31 \%$ & $46,23 \%$ \\
\hline
\end{tabular}

Sumber : DJP AR 2015- LAKIN DJP 2016

Penelitian tentang pengaruh intellectual capital terhadap kualitas informasi akuntansi telah dilakukan oleh Munthe dan Hutapea (2014), Citro dan Widyawati (2014), Fadri (2016), dan Hussain et al. (2016). Hasil penelitianya dari para peneliti ini semuanya signifikan, tetapi tidak konsisten dalam arah pengaruhnya. Ada yang berpengaruh positif dan ada juga yang berpengaruh negatif. Perbedaan arah pengaruh dalam penelitian ini menyebabkan belum bisa diambil kesimpulan yang kuat, sehingga membutuhkan informasi hasil penelitian selanjutnya. Penelitian tentang pengaruh solvabilitas terhadap kualitas informasi akuntansi telah dilakukan oleh Susilawati (2012), Dewi (2016), Khimat dan Rehman (2014), Aziz, Kajananthan dan Velnamphy, dan Rahman (2017). Hasil para peneliti ini juga masih belum konsistten, terutama untuk arah pengaruhnya, masih terdapat pengaruh yang positif dan pengauh yang negatif. Penelitian tentang pengaruh kualitas informasi akuntansi terhadap efektive tax rate telah dilakukan oleh Indarti dan Winoto (2015). Penelitian tentang pengaruh intellectual capital terhadap efektive tax rate telah dilakukan oleh Anovar dan Houria (2017). Penelitian tentang pengaruh solvabilitas terhadap efektive tax rate telah dilakukan oleh Dewinta dan Setiawan (2014), Puspitasari (2014), Kurniasih dan Sari (2014) dan Nursari et al. (2017). Hasil hasil penelitian ini belum kuat dalam mendukung teori yang sudah ada. Hasil penelitian masih bervariasi sehingga belum bisa digeneraliasi sebagai suatu kepastian. Masih butuh pembuktian lebih lanjut tentang variabel variabel yang diteliti ini. Untuk pengaruh tidak langsung dari intellectual capital dan solvabilitas terhadap efektive tax rate melalui kualitas informasi akuntansi, belum ditemukan. Penelitian ini ditujukan sekaligus untuk mengisi kekosongan ini.

\section{LITERATURE RIVIEW DAN HIPOTES IS \\ Agency Theory}

Teori keagenan (Agency Theory) merupakan suatu hubungan kontraktual antara principles dan agents. Dimana principles adalah yang memberikan tugas kepada pihak lain, yaitu agents yang akan melakukan semua kegiatan atas nama principals dalam kapasitasnya sebagai pengambil keputusan (Jensen dan Meckling, 1976). Adanya hubungan anatara kedua belah pihak diantara kepemilikan dan pengelolaan perusahaan untuk saling mendapatkan hasil laba yang diperoleh. Para pimpinan perusahaan yang mengelola perusahaan merupakan agen dari para pemilik modal atau investor. Efektive tax rate merupakan informasi porsi pajak yang tersaji dalam laba yang diperoleh perusahaan. Pajak tersebut seyogyanya dikelola dan direncanakan dengan baik. Nilai porsi pajak tentunya tidak terlepas dari kualitas laporan keuangan yang disajikan oleh manajemen perusahaan. Peran serta para manajer tidak terlepas dari beban intellectual capital yang telah diinvestasikan oleh perusahaan, dengan harapan sumberdaya yang dimiliki perusahaan mampu mengelola perusahaan dengan baik. Semua sumber daya harus dikelola dengan baik, termasuk hutang yang dimiliki perusahaan, harus mendapat perhatian ekstra. Manajemen hutang yang sehat adalah pengelolaan hutang yang mampu menghasilkan income untuk menutupi pembayaran bunga dan pengembalian hutang itu sendiri.

\section{Pengaruh Intellectual Capital Terhadap Kualitas Informasi Akuntansi}

Metode yang ditemukan oleh Pulic (1998) ini lebih dikenal dengan Value Added Intellectual Efficiency Method (VAIC), bertujuan untuk menyajikan informasi tentang value creation efficiency dari aset berwujud (tangible asset) dan aset tidak berwujud (intangible assets) yang dimiliki oleh perusahaan. Pengukuran yang dipakai ialah $V A$ yaitu menciptakan nilai tambah, VAHU mengidentifikasikan modal manusia untuk nilai perusahaan, STVA yaitu modal structural untuk menciptakan nilai, dan $V A C A$ sebagai modal internal untuk menciptakan nilai. Menurut penelitian Fadri (2016) intellectual capital $\left(V A I C^{T M}\right)$ berpengaruh terhadap kinerja perusahaan. Penelitian ini juga berhasil membuktikan bahwa intellectual capital berpengaruh terhadap kualitas informasi akuntansi. Pada penelitian Munte dan Hutapea (2014) VA berpengaruh positif terhadap perusahaan, sedangakan penelitian Hussain et al. (2016) berpengaruh negativf. Penelitian Citro dan Widyawati (2014) VAIC berpengaruh positif. Dari uraian tersebut, hasil penelitian belum konsisten setiap tahunnya, dan masih membutuhkan pembuktian lebih lanjut. Berdasarkan penjelasan diatas, maka ditetapkan hipotesis pertama dalam penelitian ini yaitu : $\mathrm{H}_{1}$ : Intellectual capital berpengaruh signifikan terhadap kualitas informasi akuntansi. 


\section{Pengaruh Solvabilitas Terhadap Kualitas Informasi Akuntansi}

Solvabilitas dapat diukur dengan Debt to equity Ratio (DER). Rasio solvabilitas ini bertujuan untuk melihat ukuran pembelanjaan dengan hutang. Menurut Darsono (2005) rasio ini menunjukkan persentase penyediaan dana oleh pemegang saham kepada pemberi pinjaman. Semakin tinggi rasio, semakin rendah pendanaan perusahaan yang disediakan oleh pemegang saham. Informasi memberikan data untuk melihat dan mengukur keadaan sutu perusahaan yang berupa hasil output seperti laporan keuangan sehubungnya dengan solvabilitas. Pada penelitian Susilawati (2012) solvabilitas menunjukkan pengaruh yang signifikan terhadap kualitas informasi akuntansi. Penelitian lainnya dilakukan Dewi (2016) dan membuktikan bahwa DER berpengaruh negatif dan signifikan terhadap informasi di laporan keuangan. Pada penelitian Khimat dan Rehman (2014) terbukti berpengaaruh negatif tidak konsisten dengan penelitian sebelumnya. Dalam penelitian lainnnya Aziz dan Rahman (2017) serta penelitian Kajananthan dan Velnampy (2014) terbukti berpengaruh negatif dan tidak konsisten dengan penelitian sebelumnya. Dari uraian diatas, dapat disimpulkan bahwa pengaruhnya belum konsisten dan arah pengaruh masih bervariasi positif dan negatif. Dibutuhkan penelitian lanjutan untuk membuktikan hal ini. Berdasarkan pada uraian diatas, maka ditetapkan hipotesis kedua dalam penelitian ini yaitu: $\mathrm{H}_{2}$ : Solvabilitas berpengaruh signifikan terhadap kualitas informasi akuntansi.

\section{Hubungan Kualitas Informasi Akuntansi Terhadap Effective Tax Rate}

Konsep kualitas informasi akuntansi adalah sebuah konsep bagaimana informasi akuntansi menjadi pegangan keputusan bedasarkan data yang disajikan dalam bentuk laporan secara kuantitatif maupun kualitatif. Analisis factor fundanmental umumnya berkaitan dengan rasio- rasio keuangan seperti cash flow, ROA, dan yang lain berkaitan dengan laporan keuangan. Dalam Indarti dan Winoto (2015) pengaruh $R O A$ positif terhadap penghindaran pajak dikarenakan perusahaan mampu mengelola asetnya dengan baik, sehingga memperoleh keuntungan dari insentif pajak dan kelonggaran pajak. Pada akhirnya perusahaan tersebut bisa dikatakan melakukan penghindaran pajak. Bedasarkan uraian tersebut, maka ditetapkan hipotesis ketiga dalam penelitian ini yaitu : $\mathrm{H}_{3}$ : Kualitas informasi akuntansiberpengaruh signifikan terhadap effective tax rate.

\section{Pengaruh Intellectual Capital Terhadap Fffective Tax Rate}

Intellectual Capital merupakan materi intelektual yang telah diformalisasikan, ditangkap, dan diungkit untuk menciptakan kekayaan, dengan menghasilkan suatu aset yang bernilai tinggi (Widiatmoko, 2015). Intellectual capital merupakan ukuran utuk melihat ukuran tangible assets atau intangible, mencangkup teknologi, informasi, human capital, brand image dalam meciptakan nilai bagi perusahaan. Penelitian yang berkaitan dengan Intelectual capital dilakukan oleh Anovar dan Houria (2017) membuktikan bahwa hal tersebut berdampak positif terhadap aktivitas perpajakan. Intellectual Capital juga berpengaruh terhadap Tax Avoidance sebagai pengukuran dari perencanaan pajak. Bedasarkan uraian tersebut, maka ditetapkan hipotesis keempat dalam penelitian ini yaitu: $\mathrm{H}_{4}$ : Intellectual Capital berpengaruh signifikan terhadap effective tax rate.

\section{Pengaruh Solvabilitas Terhadap Effective Tax Rate}

Leverage merupakan penggunaan sumber- sumber pembiayaan perusahaan baik itu sumber jangka panjang maupun jangka pendek. Menurut Nursari, et al. (2017) rasio leverage atau solvabilitas ini merupakan rasio yang menghitung utang dan modal menggunakan Debt to Equity Ratio. Penelitian terkait dengan leverage yang dilakukan oleh Dewinta dan Setiawan (2014). Hasil penelitian membuktikan bahwa leverage tidak berpengaruh terhadap tax avoidance, artinya tinggi rendahnya leverage tidak akan mempengaruhi aktivitas tax avoidance di perusahaan. Penelitian lain dilakukan oleh Puspitasari (2014) dan membuktikan bahwa leverage tidak berpengaruh terhadap tax avoidance. Dalam penelitian Nursari, et al., (2017) solvabilitas terbukti berpengaruh terhadap tax avoidance. Kemudian penelitian lainnya dilakukan oleh Kurniasih dan Sari (2014), hasilnya rasio solvabilitas tidak berpengaruh secara signifikan terhadap effective tax rate. Berdasarkan uraian tersebut, maka ditetapkan perlu kembali diuji dengan hipotesis kelima dalam penelitian ini yaitu: $\mathrm{H}_{5}$ : Solvabilitas berpengaruh signifikan terhadap effective tax rate.

\section{Pengaruh Intellectual Capital Terhadap ETR Melalui Kualitas Informasi Akuntansi}

Menurut Faradina, et al. (2016) Intellectual Capital memenuhi kriteria sebagai sumber daya yang unik apabila mampu menciptakan keunggulan kompetitif bagi perusahaan, sehingga mampu menciptakan nilai bagi perusahaan dan dapat menguasai serta memanfaatkan Intellectual Capital. Langkah dalam mengukur VAIC ${ }^{\mathrm{TM}}$ adalah dengan menilai hubungan antara VA dan modal (HC). Hubungan antara VA dan HC mengindikasikan kemampuan modal manusia untuk menciptakan nilai bagi perusahaan. Dalam penelitian Siregar (2016) Capital Intellectual berpengaruh negatif terhadap Tax Avoidance. Penelitian lain yang berkaitan dengan Intellectual Capital dengan menguji hubungannya dengan kualitas informasi akuntansi dilakukan oleh Putri, et al., 2016. Capital intellectual dan informasi akuntansi berpengaruh secara bersamasama terhadap ETR. Bedasakan uraian tersebut, maka ditetapkan hipotesis keenam dalam penelitian ini yaitu: $\mathrm{H}_{6}$ : Intellectual Capittal berpengaruh signifikan terhadap effective tax rate melalui kualitas informasi akuntansi. 


\section{Pengaruh Solvabilitas Terhadap ETR Melalui Kualitas Informasi Akuntansi}

$D E R$ dapat memberikan gambaran mengenai struktur modal yang dimiliki oleh perusahaan sehingga dapat dilihat tingkat risiko tak terbayarkan suatu hutang. Dewi (2016). Informasi akuntansi merupakan kandungan informasi yang dapat diperoleh dari laporan keuangan perusahaan melalui teknik analisis fundamental. Menurut Nurfadilah, et al., (2016) Solvabilitas tidak berpengaruh terhadap Effective Tax Rate. Peneltian lain Wulansari, et al., (2014) menunjukkan bahwa leverage mempunyai peranan yang penting dalam pendanaan utang bagi perusahaan. Penelitian ini juga membuktikan biaya bunga timbul dari utang tersebut, berpengaruh pada beban pajak perusahaan, sehingga dampak solvabilitas berpengaruh negatif terhdaap effektivitas tax rate. Berdasarkan uraian tersebut, maka perlu dilakukan penelitian kembali. Ditetapkan hipotesis ketujuh dalam penelitian ini yaitu : $\mathrm{H}_{7}$ : Solvabilitas berpengaruh terhadap effective tax rate melalui kualitas informasi akuntansi.

\section{METODE PENELITIAN}

Penelitian ini termasuk dalam jenis penelitian kausatif. Penelitian kausatif merupakan penelitian yang menunjukkan hubungan sebab akibat antara dua variabel atau lebih. Tujuan dari penelitian ini yaitu untuk melihat pengaruh suatu variabel terhadap variabel lainnya. Penelitian ini menjelaskan dan menggambarkan pengaruh solvabilitas dan intellectual capital terhadap effective tax rate dan kualitas informasi akuntansi sebagai variabel mediasi. Metode pengambilan sampel dalam penelitian adalah metode purposive sampling yaitu sampel yang dipilih berdasarkan pada kondisi khusus yang dianggap mampu menunjukkan karakter populasi. Penelitian mengambil sampel penelitian dari kelompok industri barang konsumsi, dengan kriteri menghasilkan laba dan pajak selama periode penelitian. Periode penelitian selama lima tahun, sejak tahun 2013 sampai tahun 2017.

\section{Variabel Dependen (Y)}

Effective tax rate (ETR) adalah tingkat pajak efektif perusahaan yang dapat dihitung dari beban pajak penghasilan (beban pajak kini) yang kemudian dibagi dengan laba sebelum pajak. "Semakin rendah nilai effective tax rate (ETR) maka semakin baik nilai effective tax rate (ETR) disuatu perusahaan dan baiknya nilai effective tax rate (ETR) tersebut menunjukkan bahwa perusahaan tersebut telah berhasil melakukan perencanaan pajak (Wulandari dan Septiari (2015). Dalam kaitanya dengan dengan effective tax rate (ETR) Ada beberapa cara untuk mengukurnya misalnya Tax Avoidance. Tax avoidance adalah usaha pengurangan pajak, namun tetap mematuhi ketentuan peraturan perpajakan seperti memanfaatkan pengecualian dan potongan yang diperkenankan maupun menunda pajak yang belum diatur dalam peraturan perpajakan yang berlaku dan biasanya melalui kebijakan yang diambil oleh pimpinan perusahaan (Dewinta dan Setiawan, 2016). Hal ini berkaitan dengan tindakan yang dilakukan perusahaan untuk menentukan pengukuran pajak secara legal atau diperbolehkan. Variabel dependen merupakan varibel yang dapat dipengaruhi atau yang menjadi akibat dari varibel indepenen. Varibel dependen disini adalah Effective Tax Rate. Effective Tax Rate dapat diproksikan ke dalam Tax avoidance. Tax avoidanvce merupakan pengukuran perusahaan terhadap penghindaran pajak yang dilakukan secara legal dengan tidak melangar undang - undang yang ada. Dalam penelitian ini tax avoidance di formulasikan ke dalam model tax rate Cash Effective Tax Rate (CETR) yang diharapkan akan mampu mengidentifikasi keagresifan perencanaan pajak perusahaan yang dilakukan menggunakan perbedaan tetap maupun perbedaan temporer (Chen et al., 2010). CETR dihitung dengan rumus: jumlah pembayaran pajak / laba sebelum pajak. Menurut Nurfadilah et al. (2016) ETR merupakan ukuran hasil berbasis pada laporan laba rugi yang secara umum mengukur efektifitas dari strategi pengurangan pajak dan mengarahkan pada laba setelah pajak yang tinggi.

\section{Variabel Independen $(\mathbf{X})$}

Variabel independen merupakan variabel yang menjelaskan atau mempengaruhi variabel lain. Dalam penelitian ini terdapat dua variabel independen yakni Solvabilitas dan Intellectual Capital.

a. Solvabilitas, merupakan rasio yang digunakan untuk mengukur kemampuan suatu perusahaan menggunakan hutang, salah satu proksi yang digunakan ialah DER atau Debt To Equity Ratio yang dihitung dengan rumus total kewajiban / modal sendiri.

b. Intellectual Capital dalam Nilai VAIC ${ }^{\mathrm{TM}}$ dapat dihitung melalui beberapa langkah:

1. $\quad \mathrm{VA}=\mathrm{OUT}-\mathrm{IN}$

Keterangan :

OUT = pendapatan seluruh produkdan jasa yang dijual

IN = seluruh biaya perusahaan, kecuali biaya karyawan

2. $\mathrm{VAHU}=\mathrm{VA} / \mathrm{HC}$

Keterangan :

VA = nilai tambah perusahaan

$\mathrm{HC}=$ total gaji dan upah karyawan

3. STVA $=$ SC $/$ VA 


$$
\begin{array}{ll}
\mathrm{SC} & =\text { modal struktural }(\mathrm{VA}-\mathrm{HC}) \\
\mathrm{VA} & =\text { nilai tambah perusahaan }
\end{array}
$$

4. VAICTM $=$ VACA + VAHU + STVA

\section{Variabel Intervening $(Z)$}

Kualitas informasi akuntansi bagi perusahaan yang terdaftar di pasar modal mempunyai peranan sangat penting dalam membentuk pas ar modal yang efisien. Informasi akuntansi dalam arti bentuk dan isinya dapat mempunyai pengaruh yang kuat terhadap proses pengambilan keputusan investasi (Puspitaningtyas, 2012). Konsep kualitas informasi akuntansi memberikan pengaruh bagaimana informasi akuntansi menjadi pegangan keputusan bedasarkan data yang disajikan dalam bentuk laporan secara kuantitatif maupun kualitatif. Be berapa pendekatan untuk mencerminkan pengakuan investor terhadap kualitas informasi akuntansi, Seperti karakteristik pendapatan serta menggunakan perusahaan harga saham untuk mengukur kualitas informasi akuntansi sebagai karakteristik terkait pendapatan bedasarkan laporan keuangan, dengan mengembangkan empat ukuran menentukan kualitas informasi akuntansi, seperti kualitas akrual, persistensi pendapatan, prediktabilitas laba dan penghalusan laba, serta juga mengkostruktif pengukuran yang komperensif dengan keempat pengukuran diatas. Variabel Intervening merupakan variabel yang terletak diantara variabel independen dengan varibael dependen. Variabel intervening merupakan variabel perantara, yang dapat berfungsi sebagai variabel independen dan sekaligus sebagai variabel dependen. Variabel kualitas informasi akuntansi menggunakan proksi income smoothing atau perataan laba dihitung berdasarkan pergeseran antara akrual dan laba bersih, yang dapat diukur dengan rasio deviasi standar laba bersih terhadap arus kas operasi, atau oleh korelasi antara perubahan akrual dan arus kas operasi pada periode berjalan.

\section{HASIL PENELITIAN}

Metode pengambilan sampel dalam penelitian adalah metode purposive sampling yaitu sampel yang dipilih berdasarkan pada kondisi khusus yang dianggap mampu menunjukkan karakter populasi. Diperoleh 20 sampel perusahaan industry barang konsumsi untuk periode penelitian tahun 2013 sampai tahun 2017. Total data penelitian yang di run adalah 100 data penelitian. Berikut hasil pengujian hipotesis dengan menggunakan bantuan software stata.

\section{Pengujian Hipotesis untuk Model Pertama}

Metode analisis menggunakan metode estimasi ordinary least square, untuk model yang menguji pengaruh langsung. Sebelum pengujian hipotesis ini dilakukan, terlebih dahulu telah dipastikan bahwa model ini lolos dari uji asumsi klasik dan telah dilakukan pemilihan model terbaik dari persamaan ini. Uji model yang paling ses uai dilakukan melalui Chow Test, LM Test, Hausman Test, dan model yang terbaik adalah comment effect. Berikut hasil run dengan menggunakan software stata untukmenguji hipotesis pada model pertama.

Tabel 1. Pengaruh Intellectual Capital dan Solvabilitas Terhadap Kualitas Informasi Akuntansi

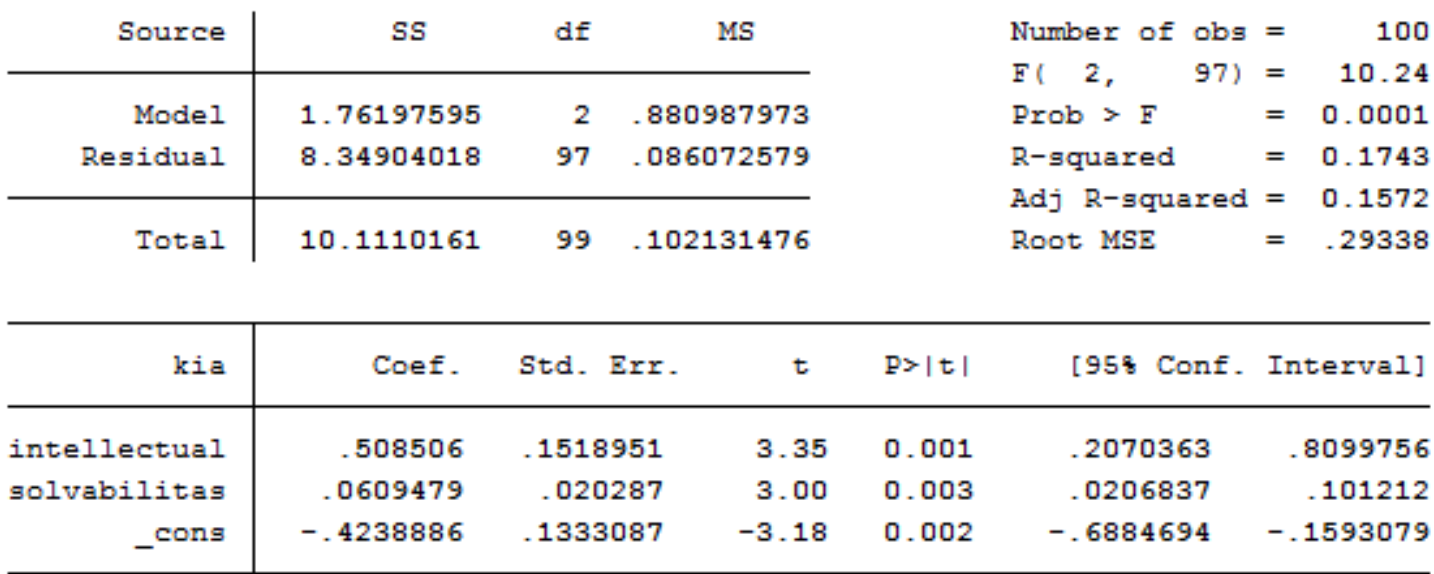

Sumber: Hasil Pengolahan Data dengan Stata, 2018.

Hasil pengolah data pada tabel 1 diatas menunjukkan hasil Probablitas > F sebesar 0,001 berada dibawah 5\% memberi arti bawa model yang diuji baik dan memberikan makna. Tabel 1 memberikan informasi bahwa intellectual capital berpengaruh signifikan terhadap kualitas informasi akuntansi, dibuktikan dengan nilai $\mathrm{t}$ sebesar 3,35 > 1,96 dan nilai $\mathrm{p}$ value sebesar 0,001 <0,05. Artinya hipotes is penelitian yang pertama diterima. Penelitian ini berhasil membuktikan bahwa intellectual capital merupakan bagian penting dari kualitas informasi 
akuntansi. Intellectual capital dapat dijadikan sebagai indikator jika ingin meningkatkan kualitas informasi akuntansi. Pembebanan untuk sumber daya manusia telah berhasil mempengaruhi penyajian dan kualitas informasi akuntansi. Penelitian ini memberi bukti bahwa semakin besar biaya yang terkait dengan intellectual capital, maka kualitas informasi akuntansi akan semakin tinggi. Hasil penelitian ini memperkuat hasil penelitian terdahulu yang dilakukan oleh Munthe dan Hutapea (2014) dan peneliti Citro dan Widyawati, karena menghasilkan dampak yang sama, yaitu positif dan signifikan. Demikian juga dengan solvabilitas perusahaan, terbukti berpengaruh signifikan terhadap kualitas informasi akuntansi, dibuktikan dengan nilai t sebesar 3,00 > 1,96 dan nilai $\mathrm{p}$ value sebesar $0,003<0,05$. Artinya hipotesis penelitian yang kedua dapat diterima. Penelitian ini berhasil membuktikan bahwa keberadaan hutang tidak menjadi penghalang untuk menyajikan laporan keuangan yang berkualitas. Laporan keungan yang berkualitas memiliki makna bahwa laporan keungan berisi informasi yang bisa dipertanggungjawabkan keberadaan dan jumlahnya, serta faktor accrual dapat diminimalisasi. Hasil penelitian ini memperkuat hasil penelitian terdalu yang dilakukan oleh Susilawati (2012), yakni menghasilkan pengaruh yang positif dan signifikan.

\section{Pengujian Hipotesis untuk Model Kedua}

Metode analisis menggunakan metode estimasi ordinary least square, untuk model yang menguji pengaruh langsung. Sebelum pengujian hipotesis ini dilakukan, terlebih dahulu telah dipastikan bahwa model ini lolos dari uji asumsi klasik dan telah dilakukan pemilihan model terbaik dari persamaan ini. Uji model yang paling sesuai dilakukan melalui Chow Test, LM Test, Hausman Test, dan model yang terbaik adalah comment effect. Berikut hasil run dengan menggunakan software stata untuk menguji hipotesis pada model penelitian yang kedua.

Tabel 2. Pengaruh Intellectual Capital dan Solvabilitas Terhadap ETR

\begin{tabular}{|c|c|c|c|c|c|c|}
\hline Source & ss & df & MS & Number of obs & $=$ & 100 \\
\hline & & & & $E(3$, & $=$ & 10.67 \\
\hline Model & 228.415783 & 3 & 76.1385942 & Prob $>F$ & $=$ & 0.0000 \\
\hline Residual & 685.206727 & 96 & 7.13757008 & R-squared & $=$ & 0.2500 \\
\hline & & & & Adj R-squared & $=$ & 0.2266 \\
\hline Total & 913.62251 & 99 & 9.2285102 & Root MSE & $=$ & 2.6716 \\
\hline
\end{tabular}

\begin{tabular}{r|rrrrrr}
\hline etr & Coef. & Std. Err. & $t$ & p > t I & [958 Conf. Interval] \\
\hline kia & 2.971416 & .9246064 & 3.21 & 0.002 & 1.136087 & 4.806745 \\
intellectual & 4.91881 & 1.460929 & 3.37 & 0.001 & 2.018889 & 7.81873 \\
solvabilitas & -.1438009 & .1931438 & -0.74 & 0.458 & -.5271884 & .2395865 \\
_cons & 2.379778 & 1.275651 & 1.87 & 0.065 & -.1523698 & 4.911926 \\
\hline
\end{tabular}

Sumber: Hasil Pengolahan Data dengan Stata, 2018.

Hasil pengolah data pada tabel 1 diatas menunjukkan hasil Probablitas > F sebesar 0,000 berada dibawah 5\% memberi arti bawa model yang diuji baik dan memberikan makna. Tabel 2 memberikan informasi bahwa kualitas informasi akuntansi berpengaruh signifikan terhadap efektif tax ratio, dibuktikan dengan nilai t sebesar $3,21>1,96$ dan nilai $\mathrm{p}$ value sebesar $0,002<0,05$. Artinya hipotesis penelitian yang ketiga diterima. Penelitian ini berhasil membuktikan bahwa kualitas informasi akuntansi berperan penting dalam usaha peningkatan efisiensi pajak. Kualitas informasi akuntansi mampu berdiri sendiri mempengaruhi efisiensi pajak perusahaan. Kualitas informasi akuntansi dapat dijadikan sebagai indicator jika ingin meningkatkan efisiensi pajak perusahaan. Hasil penelitian ini memperkuat hasil penelitian terdahulu yang dilakukan oleh Indarti dan Winoto (2015). Demikian juga dengan hipotesis keempat berhasil dibuktikan, bahwa intellectual capital berpengaruh signifikan terhadap efektive tax rate. Artinya hipotesis keempat dapat diterima karena nilai t sebesar 3,37> 1,96 dan nilai $\mathrm{p}$ value sebesar $0,001<0,05$. Dengan demikian dapat disimpulkan bahwa intellectual capital menjadi sangat penting untuk mencapai efektivitas pajak perusahaan. Untuk meningkatkan efektivitas pajak perusahaan dapat dilakukan melalui peningkatan beban intellectual capital. Intellectual capital berpegaruh positif dan signifikan, semakin besar intellectual capital akan memberikan dampak yang bersar terhadap efektivitas perpajakan perusahaan. Hasil penelitian ini memperkuat hasil penelitian terdahulu yang dilakukan oleh Anovar dan Houria (2017). Sedangkan untuk hipotesis yang kelima gagal dibuktikan dalam penelitian ini. Solvabilitas terbukti tidak berpengaruh signifikan terhadap efektive tax rate. Hal ini berarti bahwa solvabilitas tidak bisa memberikan dampak yang berarti untuk efektivitas pajak perusahaan. Pengaruh yang tidak signifikan ini sejalan dengan penelitian terdahulu yang dilakukan oleh Dewinta dan Setiawan (2014), Kurniasih dan Sari (2014), serta penelitian yang dilakukan oleh Puspitasari (2014), 


\section{Pengujian Hipotesis untuk Model Ketiga}

Untuk pengujian pengaruh tidak langsung, digunakan metode two least square dengan struktur data panel. Hasil pengujian data ini dapat dilihat pada tabel 3 .

Tabel 3. Pengaruh Intellectual Capital dan Solvabilitas Terhadap ETR

Melalui Kualitas Informasi Akuntansi

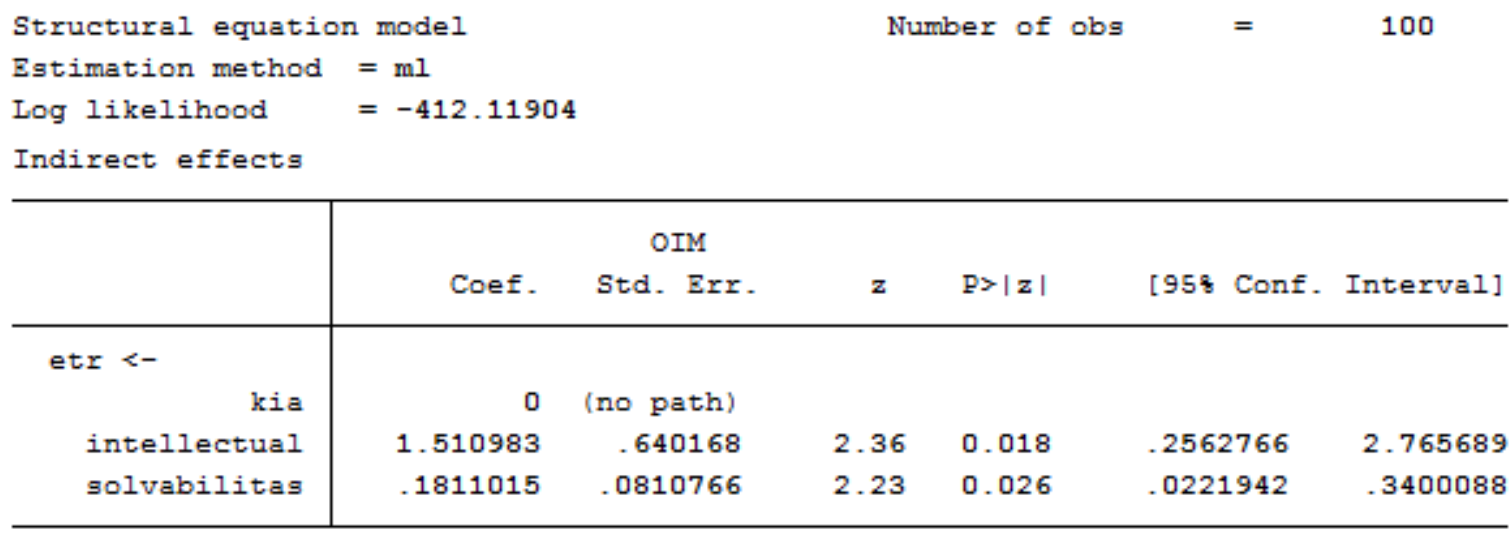

Sumber: Hasil Pengolahan Data dengan Stata, 2018.

Tabel 3 memberikan informasi bahwa intellectual capital berpengaruh signifikan terhadap efektif tax ratio melalui kualitas informasi akuntansi, dibuktikan dengan nilai z sebesar 2,36 > 1,96 dan nilai $\mathrm{p}$ value sebesar $0,018<0,05$. Dengan demikian hipotesis keenam dalam penelitian ini dapat diterima. Artinya kualitas informasi akuntansi dapat memediasi secara signifikan pengaruh dari intellectual capital terhadap efektive tax rate. Intellectual capital bila didukung dengan kualitas informasi akuntansi, akan menghasilkan efektivitas pajak yang baik. Hasil penelitian ini melengkapi penelitian yang sudah dilakukan oleh Siregar (2016) yang menyatakan bahwa intellectual capital dan informasi akuntansi secara bersama sama berpengaruh terhadap ETR. Demikian juga dengan hipotesis yang ketujuh dapat dibuktikan dalam penelitian ini. Terbukti bahwa nilai z sebesar 2,23 > 1,96 dan nilai $\mathrm{p}$ value sebesar 0,026 < 0,05. Dengan demikian hipotesis ketujuh dalam penelitian ini dapat diterima. Hal ini memberi arti bahwa kualitas informasi akuntansi mampu memediasi pengaruh dari solvabiltas terhadap efektif tax rate. Solavabiltias bila ditopang oleh kualitas informasi akuntansi yang baik dapat menghasilkan efektivitas pajak perusahaan.

\section{KESIMPULAN DAN SARAN}

Hasil penelitian ini memberikan informasi yang bermanfaat bagi manajemen perusahaan dalam mengelola intellectual capital, dalam mengelola hutang perusahaan, mengelola kualitas informasi akuntansi dan mengelola efektivitas perpajakan perusahaan. Penelitian ini berhasil membuktikan bahwa intellectual capital dan solvabilitas memiliki dampak yang signifikan terhadap kualitas informasi akuntansi. Intellectual capital dapat dijadikan sebagai indikator peningkatan kualitas informasi akuntansi. Jikan ingin meningkatkan kualitas informasi akuntansi, maka manajemen bisa melakukannya dengan menaikkan biaya sumber daya manusia dan pengelolaan hutang yang baik. Demikian juga dengan efektivitas perpajakan perusahaan dipengauhi oleh kualitas informasi akuntansi dan intellectual capital yang dimiliki oleh perusahaan. Kualitas informasi akuntansi dan intellectual capital berdampak positif terhadap usaha peningkatan efektivitas perpajakan perusahaann. Secara tidak langsung, kualitas informasi akuntansi juga mampu memediasi pengaruh dari intellectual capital dan solvabilitas perusahaan terhadap efektivitas perpajakan perusahaan. Untuk penelitian selanjutnya dapat dilakukan dengan menempatkan variabel asimetri informasi dan aktivitas manajemen laba sebagai variabel independen. Variabel asimetri informasi dan aktivitas manajemen laba berpotensi untuk mempengaruhi kualitas informasi akutansi dan efektivitas pajak perusahaan.

\section{DAFTAR PUSTAKA}

Anovar dan Houria. 2017. International Journal of Economics, Finance and Management Sciences. The Determinants of Tax Avoidance within Corporate Groups: Evidence from Moroccan Groups. 5(1): $57-$ 65. Faculty of Law, Economics and Social Sciences, University Abdelmalek Essaâdi, Tangier, Morocco. Faculty Polydisciplinary, University Abdelmalek Essaâdi, Tetouan, Morocco. 
Aziz.A dan Rehman. 2017. International Journal Of Economics And Financial Issues. The Relationship Between Solvency Ratios And Profability Ratios; Analitycal Study In Food Industrial Companies Listed In Amman Bursa. 7(2) ; 86-93. Department of Finance and Accounting, College of Business Administration, Kingdom University, Kingdom of Bahrain.

Brigham dan Houston. (2001). Manajemen Keuangan II. Jakarta: Salemba Empat (2010). Pengantar Akuntansi Adaptasi Indonesia, Buku 2. Jakarta: Salemba Empat.

Citro V.D.C 2014. Pengaruh determinan struktur modal terhadap leverage dan speed of adjusment industri pertambagan di indonesia. Vol.2 no. 1;48-55. Universitas Kristen Petra.

Darsono, dan Ashari. 2005. Pedoman Praktis Memahami Laporan Keuangan. Yogyakarta: Andi Offset.

Dewi, P,.E. 2016. Jurnal Ilmiah Akuntansi. Pengaruh Rasio Likuiditas, Profitabilitas, Solvabilitas, Aktivitas Dan Penilaian Pasar Erhadap Return Saham. 1(2): 109-132. Universitas Pendidikan Ganesha.

Dewinta, Setiawan. 2016. E-Jurnal Akuntansi. Pengaruh Ukuran Perusahaan, Umur Perusahaan, Profitabilitas, Leverage, Dan Pertumbuhan Penjualan Terhadap Tax Avoidance. 4(3): 1584-1613. Fakultas Ekonomi dan Bisnis Universitas Udayana (Unud), Bali,Indonesia.

Fadri. 2016. Jurnal Ilmu dan Riset Akuntansi. Pengaruh Intellectual Capital Terhadap Profitabilitas Dan Produktivitas Pada Perbankan Syariah Di Indonesia. Vol. 5(11). Sekolah Tinggi Ilmu Ekonomi Indonesia (STIESIA). Surabaya.

Hussein M, H,Shahid dan M. Akmal. 2016. Arabbian Journal Bussines And Management. Effect Of Profitability And Financial Leverage On Capita Structure In Pakistan Textile Firms. Vol.6. 6;4. Pakistan.

Hutagaol, J. 2007. Perpajakan: Isu-Isu Kontemporer. Yogyakarta: Graha Ilmu.

Indarti, Winoto. 2015. Seminar and Call for paper. Pengaruh Return On Assets, Leverage, Corporate Governance, Dan Karakter Eksekutif Terhadap Tax Avoidance. 7 Oktober. Semarang.

Jensen, M. \& Meckling, W. 1976. Theoty of the Firm : Managerial Behaviour, Agency Cost and Ownership Structure. Journal of Finalcial Economic, 3, pp. 305-360.

Kajananthan R, dan Velnampy. 2014. Research Journal of Finance and Accounting. Liquidity, Solvency And Profitability Analysis Using Cash Flow Ratios And Traditional Ratios: The Telecommunication Sector In Sri Lanka. 5(23). Sri Langka.

Khimad dan Rehman. (2014). Impact Of Liquidity \& Solvency On Profitability Chemical Sector Of Pakistan. Vol.6. Is sue 3. Pakistan.

Liansheng W,Y,W,P,G W,L. 2007. State Ownership, Tax Status, and Size Effect of Effective Tax Rate in China. Journal of Accounting and Public Policy. Vol.26 No.6.

Munte,M,H,M. dan Hutapea,R,A. 2014. Analysis Of Effect On Sales Credit Profitability Companies In Duta Putra Sumatera Medan. Ekonomi Faculty. Universitas of HKBP.

Nurfadilah, Mulyati.H., Purnamasari.M., Niar.H. 2016. Syariah Paper Accounting FEB. Pengaruh Leverage, Ukuran Perusahaan Dan Kualitas Audit, Terhadap Penghindaran Pajak. h: 441-449. STIE Ahmad Dahlan Jakarta.

Nursari, Diamonalisa, Sukarmanto.E. 2017. Prosiding Akuntansi. Pengaruh Profabilitas, Leverage, dan Kepemilikan Institusional terhadap Tax Avoidance. 3(2): 260-264. Universitas Islam Bandung.

Puspitaningtyas, Z. 2012. Ekuitas: Jurnal Ekonomi dan Keuangan Akreditasi. Relevansi Nilai Informasi Akuntansi Dan Manfaatnya Bagi Investor. 6(2):164-183 .Universitas Jember.

Pus pitasari. 2014. Jurnal Akuntansi. Pengaruh Leverage, Kepemilikan Institusional, Dan Ukuran Perusahaan Terhadap Penghindaran Pajak (Tax Avoidance) Pada Perusahaan Sektor Manufaktur Yang Terdaftar Di Bursa Efek Indonesia 2010-2012. Volume XVIII, No. 03. Universitas Tarumanagara.

Putri, dan Lautania. 2016. Pengaruh Capital Intensity Ratio, Inventory Intensity Ratio, Ownership Strucutre Dan Profitability Terhadap Effective Tax Rate (Etr). Vol.1(1): 101-119. Program Studi Akuntansi. Universitas Syiah Kuala.

Siregar. 2016. Jurnal Ilmu dan Riset Akuntansi. Pengaruh Karakteristik Perusahaan Terhadap Penghindaran Pajak Pada Perusahaan Manufaktur Di Bei. 5(2): Februari. Sekolah Tinggi Ilmu Ekonomi Indonesia (STIESIA). Surabaya.

Susilawati, Christine, D,.K. 2012. Jurnal Akuntansi. Analisis Perbandingan Pengaruh Likuiditas, Solvabilitas, dan Profitabilitas Terhadap Harga Saham pada Perusahaan LQ 45. 4(2): 165-174. Universitas Kristen Maranatha.

Wang, Zhai. 2016. China Journal of Accounting Research. Accounting information quality Governance efficiency Capital investment Choice. 9(4) Desember: 251-266. China.

Widiatmoko. 2015. Pengaruh Intellectual Capital Terhadap Profitabilitas Perusahaan Manufaktur Yang Terdaftar Di Bursa Efek Indonesia. Skripsi. Program Studi Akuntansi. Universitas Negeri Yogyakarta.

Wulansari, 2014. Pengaruh Faktor Struktur Kepemilikan Dan Leverage Terhadap Tax Avoidance Pada Perusahaan Yang Terdaftar Di Bursa Efek Indonesia. Fakultas Ekonomi. Universitas Bung Hatta.

Zuliyati. 2013. Jurnal Dinamika Ekonomi \& Bisnis. Implementasi Pengelolaan Modal Intelektual (Intellectual Capital) Untuk Menciptakan Daya Saing UMKM..10(2): 105-113. Unis nu Jepara. 